\title{
[DAPHNE, LIPICA, STRICKEN LANDS]
}

daphne, lipica, stricken lands

stricken horses, stricken stamping

gelid humor, angels' work, brides

I see a fox, we ride on horseback the sea of plains

we ride on a flint zone

karst people are here $\&$ teran

castle, rilke, impeccable dreams

boats, duino, robbers in black bandanas

schloss $a b$, lock it, lock it well

i ladri vengono come vento, sticking their breasts in the air

with their black half top hats below their eyes

a widow takes a new partner, we fall among slavs

hate tripkovich, cosulich, parvenues, electricity italian! magna merda, lascia pan! leave us our jadranska banka $s v$. jakob and the districts where people are schooled ich habe zwei slawische mütter gehabt, climbing irons for kanin 